\title{
Spatio-temporal distribution and transformation of cropland in geomorphologic regions of China during 1990-2015
}

\author{
GAO Xiaoyu ${ }^{1,2}$, CHENG Weiming ${ }^{1,2,3}$, WANG Nan $^{1,2}$, LIU Qiangyi ${ }^{1,2}$, MA Ting ${ }^{1}$, \\ CHEN Yinjun ${ }^{4}$, ZHOU Chenghu ${ }^{1}$ \\ 1. State Key Laboratory of Resources and Environmental Information System, Institute of Geographic Sciences \\ and Natural Resources Research, CAS, Beijing 100101, China; \\ 2. University of Chinese Academy of Sciences, Beijing 100049, China; \\ 3. Jiangsu Center for Collaborative Innovation in Geographical Information Resource Development and \\ Application, Nanjing 210023, China; \\ 4. Institute of Agricultural Resources and Regional Planning of CAAS, Beijing 100081, China
}

\begin{abstract}
Landforms are an important factor determining the spatial pattern of cropland through allocation of surface water and heat. Therefore, it is of great importance to study the change in cropland distribution from the perspective of geomorphologic divisions. Based on China's multi-year land cover data (1990, 1995, 2000, 2005, 2010 and 2015) and geomorphologic regionalization data, we analyzed the change in cropland area and its distribution pattern in six geomorphologic regions of China over the period of 1990-2015 with the aid of GIS techniques. Our results showed that the total cropland area increased from 177.1 to 178.5 million ha with an average increase rate of $0.03 \%$. Cropland area decreased in southern China and increased in northern China. Region I (Eastern hilly plains) had the highest cropland increase rate, while the cropland dynamic degree of Region IV (Northwestern middle and high mountains, basins and plateaus) was significantly higher than that of other regions. The barycenter of China's cropland shifted from northern China to the northwest over the 25-year period. Regions IV and I were the two regions with the greatest increase of cropland. Region II (Southeastern low and middle mountains) and Region V (Southwestern middle and low mountains, plateaus and basins) were the main decreasing cropland regions. The area of cropland remained almost unchanged in Region III (Northern China and Inner Mongolia eastern-central mountains and plateaus) and Region VI (Tibetan Plateau). The loss of cropland occurred mostly in Regions I and II as a result of growing industrialization and urbanization, while the increase of cropland occurred mainly in Region IV because of reclamation of grassland and other wasteland. These analyzing results would provide fundamental information for further studies of urban planning, ecosystem management, and natural resources
\end{abstract}

Received: 2018-09-06 Accepted: 2018-11-07

Foundation: National Natural Science Foundation of China, No.41421001, No.41590845, No.41571388; National Key Basic Research Program, No.2015CB954101

Author: Gao Xiaoyu (1994-), Master, specialized in cropland use and agricultural resources management.

E-mail: gaoxy.16s@igsnrr.ac.cn

"Corresponding author: Cheng Weiming (1973-), PhD and Professor, specialized in digital geomorphology and GIS. E-mail: chengwm@1reis.ac.cn 
conservation in China.

Keywords: spatio-temporal distribution; transformation of cropland; geomorphologic regions; China

\section{Introduction}

Land use and land cover change (LUCC) is an essential part of global environment changes and plays an important role in maintaining the structure and production of ecosystems (Restrepo et al., 2017). LUCC can influence material circulation and organism processes in the terrestrial system over time and space, including water circulation, greenhouse gas emissions, resources sustainable utilization and biodiversity (Hao and Ren, 2009; Liu et al., 2014; Tian et al., 2015). Moreover, LUCC is influenced by factors such as the global economy, national policies and climate change. Since 1995, the International Geosphere and Biosphere Program (IGBP) and International Human Dimensions Program (IHDP) have developed and implemented the Land Use and Cover Change Science Research Program taking land use/cover as the core content in the research of global change. The Global Land Project (GLP) commenced in 2005 and emphasized not only the integration and simulation of the coupled human-environment system but also the effect of different management practices and policy decisions on LUCC (Turner et al., 2007; Yan et al., 2016). The dynamic monitoring and study of LUCC has become one of the most important aspects of researching global climate and environmental change.

Agricultural land is one of the most active land-use forms by human beings, which covers one third of the global surface (Yao et al., 2017; Ye et al., 2009) and plays a crucial role on regulating global climate change and ensuring food security (Ren et al., 2012). China is a large agricultural country, feeding one fifth of the world population with less than $7 \%$ of the cropland worldwide (Tian et al., 2016). The development of Chinese agriculture has been faced with resource shortages, environmental depredation and the demands of the huge population, while it is also restricted by poor agricultural production conditions (Chen, 2001). In recent years, increasing numbers of scholars have started to study topics such as regional ecological system health (Peng et al., 2017; Yang et al., 2017) and the comprehensive improvement of "empty village" phenomenon (Liu et al., 2013; Li and Wu, 2017) rather than a simple evaluation of quantity and quality in rural land use. Since the early 1990s, the process of urbanization and industrialization has been continually increasing in China. Cropland has been increasingly converted to urban land uses and has thus decreased rapidly. In response, the Central Rural Work Conference proposed the 1.2 billion ha of prime farmland as a "red line" to ensure China's food security in 2003. Furthermore, China has promulgated a series of policies and regulations to protect farmland, including returning farmland to forestland and grassland, and maintaining a dynamic balance of total arable land. However, there remains a phenomenon of providing low-quality cropland to offset losses of high-quality cropland, and thus the quality and productivity of cropland has decreased seriously. Therefore, the spatio-temporal distribution of cropland has become an important research topic in the field of LUCC. Many scholars have monitored and analyzed the change in cropland in different spatial scales and regions with the help of remote-sensing data (for example, Landsat TM/ETM+ and China-Brazil Earth Resources Satellite) (Liu et al., 2005; Liu et al., 2010; Kotoky et al., 2012; Kraemer et al., 2015; Restrepo et al., 2017; Yao et al., 2017). 
The type of land use can alter the modes and extents of exogenic force, influencing the formation, development and evolution of landform and geomorphology. Furthermore, topography and geomorphology are some of the most basic components of the ecological environment, restricting the form and effect of land use by allocating surface water and energy (Song and Chen, 1993; Zhou et al., 2009; Cheng et al., 2011; He et al., 2016). Cropland is one of the most sensitive LUCC types (Liu et al., 2001), thus geomorphologic factors play a vital role in influencing the spatio-temporal distribution and transformation of cropland. Altitude and slope affect climate factors, such as temperature and precipitation, but also restrict the difficulties in reclaiming cropland. Therefore, topography and geomorphology determine the spatio-temporal distribution of cropland and strongly influence cropland quantity and quality (Liu et al., 2001; Cheng et al., 2012; Wang et al., 2018). Extracting three typical kinds of geomorphologic types in Chongqing, Tian et al. (2010) concluded that topography and geomorphology have significant influences on the status of land use and land development. The amount of newly reclaimed cropland in deep hills is apparently higher than that in shallow hills. Cheng et al. (2012) showed that there are observably spatial differences of the cropland in diversity genetic types regions in Xinjiang based on water resource regionalization and geomorphologic characteristics. Taking Chengcheng County located in complex topography regions of Loess Plateau as an example, Fu et al. (2011) analyzed the effect on farmland productivity by loess landforms. They found that the high-quality farmland mainly distributed on the Loess Plateau with flat terrain, better irrigation and higher fertility.

At present, research about changes in cropland area influenced by topography and geomorphology are concentrated at the scale of city, county or watershed and relatively little research has been conducted at national or provincial scale (Cheng et al., 2012; He et al., 2016). Some researches relied solely on unique geomorphologic features in their study areas, and therefore, it was difficult to explore deeply the effect of topography and geomorphology on cropland in multiple geomorphologic regions (Tian et al., 2010; Fu et al., 2011; Stevens et al., 2014). Because the same climate conditions are typically found across a single geomorphologic region, it is of great importance to study the spatio-temporal distribution of China's cropland from the perspective of several first-class geomorphologic divisions. According to the topographical and geomorphologic conditions, we divided China's cropland into six regions. We then quantified and described the spatio-temporal distribution of cropland in China during 1990-2015 based on the national land use and land cover database interpreted by remote sensing images. Our study can provide basic information for further study of urban landscape planning, ecosystem management and protection. Moreover, data related to the conversions between cropland and other land-use types at spatio-temporal scales can be used as reference for utilization and management of agricultural resources, natural disasters, diseases and food security.

\section{Data and methods}

\subsection{Data sources}

In this research, geomorphologic regionalization data and cropland data from 1990 to 2015 were used for analyzing spatio-temporal distribution and transformation of cropland in China. 


\subsubsection{Geomorphologic regionalization data}

Geomorphologic regionalization data were acquired from China's State Key Laboratory of Resources and Environmental Information Systems (LREIS). Based on the regional differentiation and genesis of essential geomorphologic types, we divided the entire country into six major geomorphologic regions (Li et al., 2013; Zhao et al., 2017), including Region I (Eastern hilly plains), Region II (Southeastern low and middle mountains), Region III (Northern China and Inner Mongolia eastern-central mountains and plateaus), Region IV (Northwestern middle and high mountains, basins and plateaus), Region V (Southwestern middle and low mountains, plateaus and basins) and Region VI (Tibetan Plateau) (Figure 1).

\subsubsection{Cropland data in China}

Based on the national land use and land cover database of Resource and Environment Data Center of Chinese Academy of Sciences (CAS), we acquired cropland data for 1990, 1995, 2000, 2005, 2010 and 2015. The database was supported by the National Science and Technology Supporting Plan and the Innovative Program of the CAS, covering the multi-temporal land-use status of national land area at 1:100,000 scale (Zhao et al., 2015; Liu et al., 2010; Ning et al., 2018). The database was constructed using remote-sensing images, such as Landsat TM and ETM, as the main data source based on a rapid-extraction human-computer interaction method via a high-resolution remote sensing-unmanned aerial vehicle (UAV) ground survey observation system. The land-use types include six classes, such as cropland, woodland, grassland, water body, built-up land and unused land. Through investigating and recording field data, the accuracy of the six land-use classes was above $94.3 \%$, meeting the requirement of users' mapping accuracy at 1:100,000 scale (Liu et al., 2010). Then we rasterized the land-use data at 100-m resolution for convenience. The aim of our study was to extract cropland data and analyze its spatio-temporal distribution based on geomorphologic regionalization during 1990-2015.

\subsection{Methods}

With the aid of GIS techniques, we extracted the cropland data from the national land use and land cover database for 1990, 1995, 2000, 2005, 2010 and 2015. We then analyzed the change in cropland area and its distribution pattern by overlaying analyses with data from different geomorphologic regions (Figure 1). Finally, we obtained the characteristics of cropland and other land-use types based on the transformation attribute table of croplands.

\subsubsection{Dynamic degree of cropland (DDC)}

The dynamic degree can reflect the changing ratio of the land use in different regions. The index of land-use dynamic degree proposed by Liu et al. (2005), which can comprehensively express characteristics of the distribution of land use patterns (Liu et al., 2010; Zhao et al., 2015; Ning et al., 2018). The dynamic degree of cropland (DDC) was calculated for 1990-2015 as follows:

$$
D D C=\frac{\Delta S_{i-j}+\Delta S_{j-i}}{S_{i}} \times \frac{1}{t} \times 100 \%
$$

where $S_{i}$ is the total cropland area at the start of monitoring (ha), $\Delta s_{i-j}$ is the lost cropland area during the time period (the total area of the cropland converted to others) (ha), $\Delta s_{j-i}$ is 
the newly reclaimed cropland area during the time period (the total area of the others converted to cropland) (ha), and $t$ is the period of time with a unit of year. DDC value reflects the annual change rate of cropland within the regions during the period of $t$.

(a) 1990

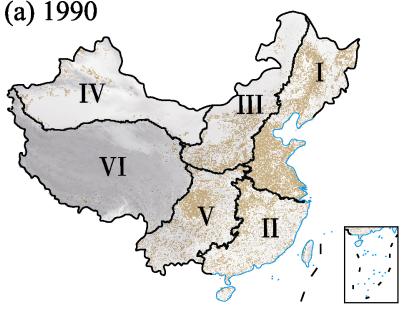

(d) 2005

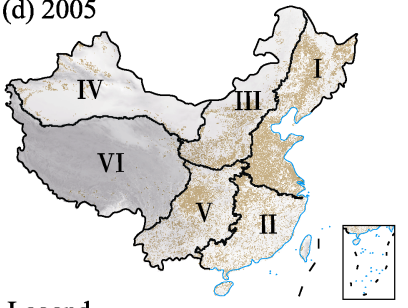

Legend

I Eastern hilly plains

II Southeastern low and middle mountains

III Northern China and Inner Mongolia eastern-central mountains and plateaus

(e) 2010 (b) 1995
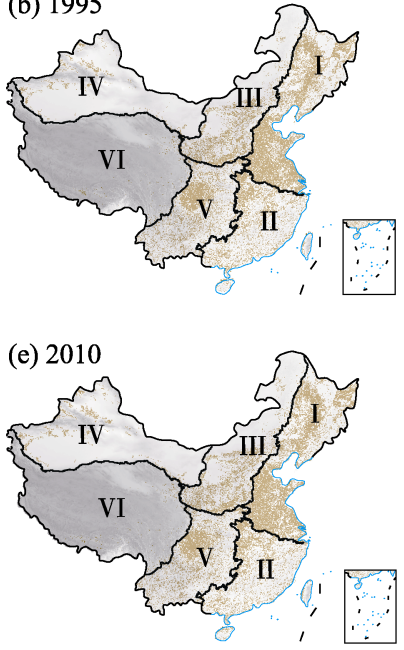

Northwestern middle and high

IV mountains, basins and plateaus

Southwestern middle and low mountains, plateaus and basins

VI Tibetan Plateau

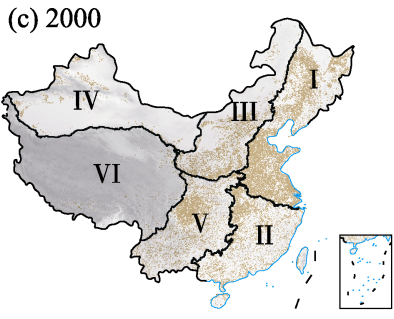

(f) 2015

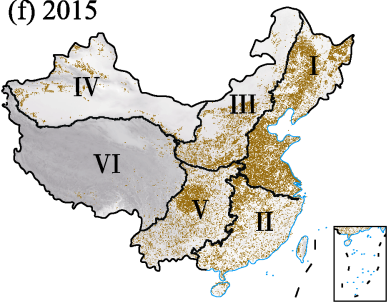

Figure 1 Distribution of China's cropland in different years

Notes: The geomorphologic regions supplemented and modified based on Li et al., 2013.

\subsubsection{Barycenter model of newly reclaimed cropland}

The barycenter model is an important tool to study the temporal and spatial variation of spatial elements during the process of regional development, which is extensively applied in the fields of urban planning and LUCC (Yin et al., 2017). The changing cropland's spatial state determines its barycenter distribution ( $\mathrm{Li}$ et al., 2017). The barycenter of the newly reclaimed cropland was calculated for 1995-2015 using the following equations:

$$
\begin{array}{r}
X_{T+1}=\frac{\sum_{i=1}^{n} M_{i} X_{i, T}}{\sum_{i=1}^{n} M_{i}} \\
Y_{T+1}=\frac{\sum_{i=1}^{n} M_{i} Y_{i, T}}{\sum_{i=1}^{n} M_{i}}
\end{array}
$$

where $X_{T+1}$ and $Y_{T+1}$ represent the barycenter (longtitude and latitude) at the end year, $M_{i}$ is the percentage of the newly reclaimed cropland area to the cropland area at the start of monitoring in the region $i, X_{i, T}$ and $Y_{i, T}$ represent the barycenter (longtitude and latitude) at the start year in region $i$, and $n$ is the count of geomorphologic regions.

However, the above equations were not applied to calculate the barycenter for 1990 be- 
cause 1990 was the start of monitoring. The equations for calculating the barycenter of 1990 were as follows:

$$
\begin{gathered}
\bar{X}=\frac{\sum_{i=1}^{n} A_{i} X_{i}}{\sum_{i=1}^{n} A_{i}} \\
\bar{Y}=\frac{\sum_{i=1}^{n} A_{i} Y_{i}}{\sum_{i=1}^{n} A_{i}}
\end{gathered}
$$

where $\bar{X}$ and $\bar{Y}$ represent the barycenter (longtitude and latitude) of national cropland in 1990, $A_{i}$ is the cropland area of the $i$ th geomorphologic region, and $X_{i}$ and $Y_{i}$ are the barycenters (longtitude and latitude) in region $i$, respectively.

\section{Results}

\subsection{Spatio-temporal distribution and transformation of cropland in China}

There was little change in the total cropland area in China (177.1 to 178.5 million ha) during the period of 1990-2015, representing an average increase of just $0.03 \%$ per year. The cropland was distributed mainly in the second and the third gradient terrain of central and eastern China (Figure 2). Splitting the data into two sections around 2000, the cropland area increased 2.8 million ha during 1990-2000, whereas it decreased 1.4 million ha during 2000-

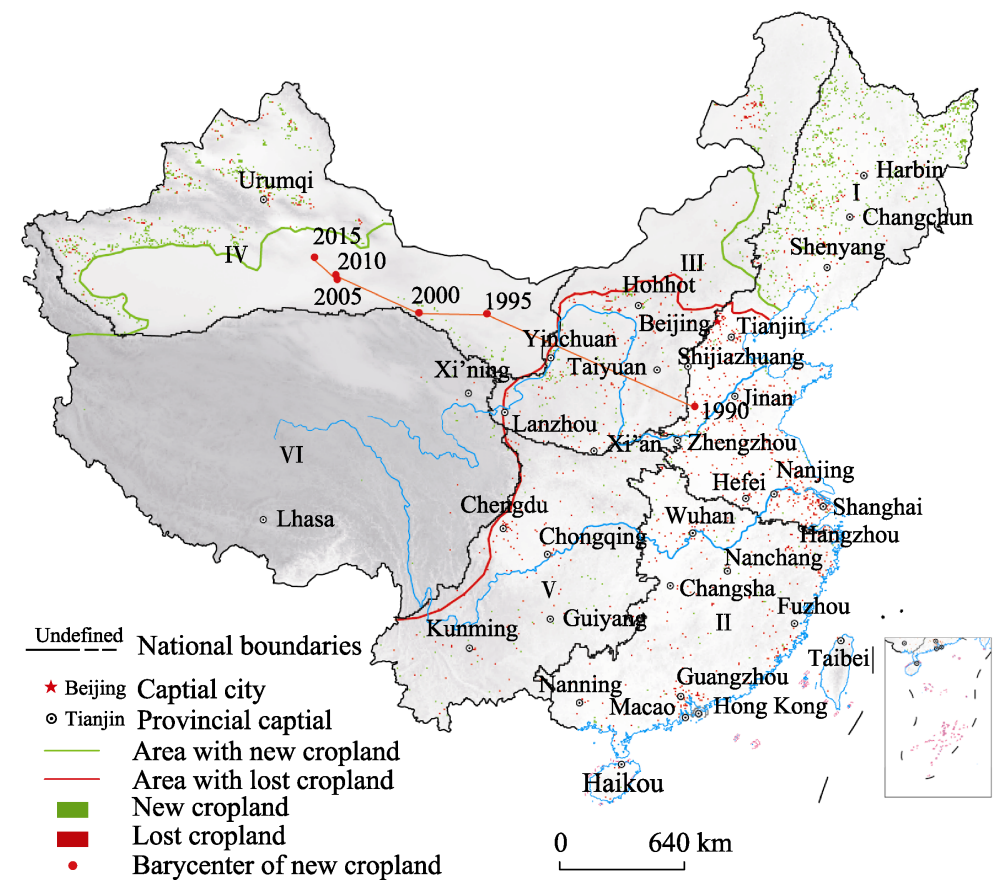

Figure 2 Distribution of the reclaimed and lost cropland in China during 1990-2015 
2015. The newly reclaimed cropland was mainly found in the northeastern and northwestern regions, with the woodland and grassland conversion to cropland. A large amount of cropland was lost in southeast coastal areas of China because of rapid urbanization.

The newly reclaimed cropland primarily came from grassland and woodland during 1990-2000, whereas it was converted from grassland and unused land during 2000-2015 (Figure 3). The area of cropland converted from built-up land was very small compared with the area from other land uses.
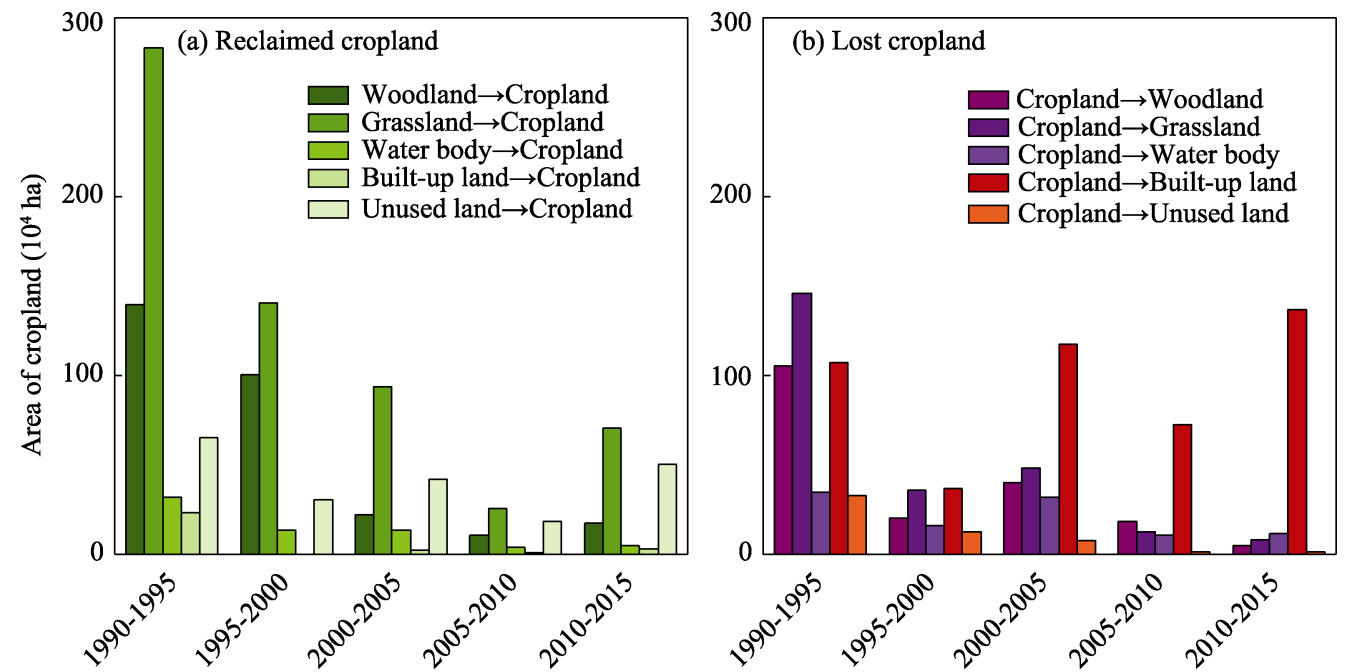

Figure 3 Land use and land cover change of reclaimed and lost cropland in China during 1990-2015

The lost cropland was mainly caused by the large expansion of built-up land, grassland and woodland. The cropland was rapidly converted to built-up land during 2000-2015, and especially the cropland area converted to built-up land accounted for $84 \%$ of all lost cropland area from 2010 to 2015 . This was because of the exceptionally rapid economic growth and the expansion of urbanization. Finally, the area of high-quality cropland was severely reduced because of construction of new buildings.

From the perspective of geomorphologic regionalization, the newly reclaimed and lost cropland was concentrated on low terrain and large plain areas (58.6\% and $60.9 \%$ respectively), followed by platforms and hills (Figure 4). The cropland decreased gradually with the increased relief amplitude (difference between the highest altitude and the lowest altitude). Plains, hills and platforms were generally preferred to be reclaimed and occupied because of the small relief amplitude $(<200 \mathrm{~m})$. In contrast, it is difficult to exploit and utilize the cropland scattered on high-relief mountains, so the limited amount of crop-

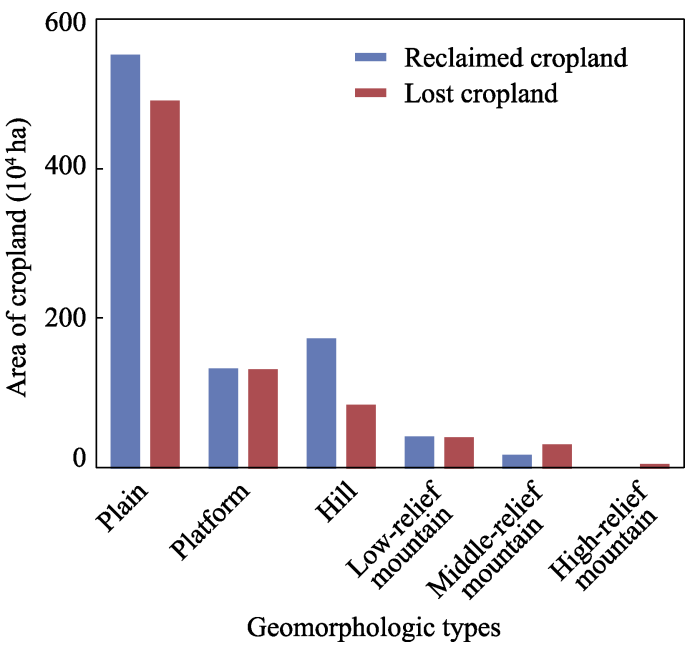

Figure 4 Change of cropland area in different geomorphologic regions in China during 1990-2015 
land available was gradually abandoned. There was small change in cropland area in high mountainous areas, and there was little cropland scattered on extremely high-relief mountains.

\subsection{Dynamic degree of geomorphologic regions}

The DDC values of different geomorphologic regions are presented in Table 1 and Figure 5. The change ranges are the total absolute areas of newly reclaimed and lost cropland. Except for Region IV, there was a slight change in cropland areas of other geomorphologic regions in the period of 1990-2015, with small average DDC values $(<1 \%)$.

Table 1 Dynamic degree of cropland (DDC) in different geomorphologic regions

\begin{tabular}{ccccccc}
\hline & \multicolumn{2}{c}{ Region I } & \multicolumn{2}{c}{ Region II } & \multicolumn{2}{c}{ Region III } \\
\cline { 2 - 7 } & $\begin{array}{c}\text { Change } \\
\text { ranges (ha) }\end{array}$ & DDC (\%) & $\begin{array}{c}\text { Change } \\
\text { ranges (ha) }\end{array}$ & DDC (\%) & $\begin{array}{c}\text { Change ranges } \\
\text { (ha) }\end{array}$ & DDC (\%) \\
\hline $1990-1995$ & $5,125,436$ & 1.40 & 940,063 & 0.56 & $1,733,440$ & 1.29 \\
$1995-2000$ & $1,981,791$ & 0.53 & 692,366 & 0.42 & 840,587 & 0.62 \\
$2000-2005$ & $1,345,601$ & 0.36 & 671,039 & 0.40 & 815,059 & 0.59 \\
$2005-2010$ & 797,084 & 0.21 & 246,073 & 0.15 & 196,102 & 0.14 \\
$2010-2015$ & 914,676 & 0.24 & 427,295 & 0.26 & 325,892 & 0.24 \\
\hline \hline & \multicolumn{2}{c}{ Region IV } & & Region V & Region VI \\
\hline $1990-1995$ & $1,380,978$ & 4.06 & 423,537 & 0.25 & 64,006 & DDC (\%) \\
$1995-2000$ & 720,985 & 2.15 & 215,656 & 0.13 & 54,301 & 0.61 \\
$2000-2005$ & 930,895 & 2.62 & 373,304 & 0.22 & 41,949 & 0.51 \\
$2005-2010$ & 335,846 & 0.85 & 276,716 & 0.16 & 18,363 & 0.39 \\
$2010-2015$ & $1,065,573$ & 2.61 & 324,831 & 0.19 & 17,915 & 0.17 \\
\hline
\end{tabular}

The cropland area increased in Region IV, with an average increase of $8.9 \times 10^{4}$ ha per year. Moreover, the cropland areas fluctuated greatly with DDC values far exceeding those of other regions. The DDC values were $4.06 \%, 2.62 \%$ and $2.61 \%$ during $1990-1995$, 2000-2005 and 2010-2015, respectively. The newly reclaimed cropland mainly stemmed from reclaiming grassland in Tarim $\mathrm{Ba}-$ sin, the Ili River Valley and Junggar Basin, owing to the mass production of cash crops, the great progress of agricultural technology and the vigorous generalization of agricultural policies.

The barycenter of China's land cultivation shifted from northern China to the northwest over the 25-year period, parts of which began in Region IV and moved northwest continuously during the period of 1995-2015 (Figure 2).

The cropland areas of Regions I and II initially increased before 2000 and then

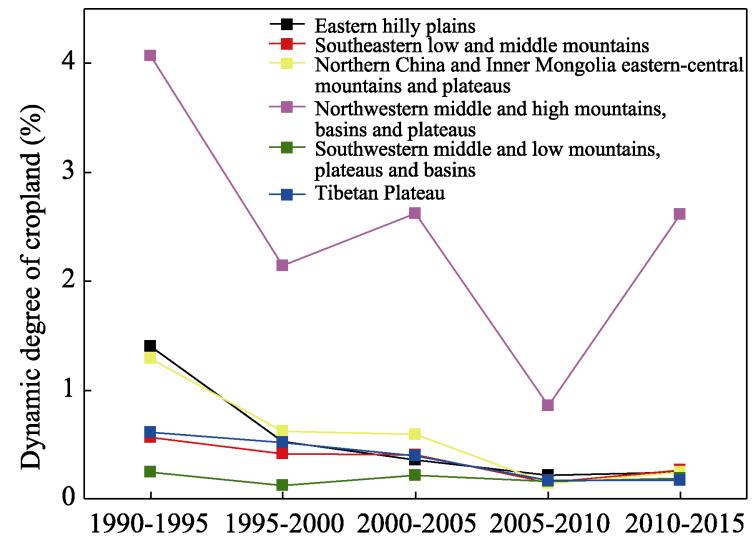

Figure 5 Change in dynamic degree of cropland (DDC) in different geomorphologic regions during 1990-2015 
decreased after 2000. The cropland area of Region I increased $5.489 \times 10^{4}$ ha annually, while that of Region III decreased $1.5 \times 10^{3}$ ha annually. The cropland areas of Regions II and V showed a decreasing trend with reducing area of $5.9 \times 10^{4}$ ha and $2.8 \times 10^{4}$ ha, respectively. However, there was little cropland and little change in Region VI, which was covered by glaciers throughout the year because of the high terrain and altitude.

\subsection{Spatio-temporal distribution of geomorphologic regions}

The spatio-temporal distribution of cropland in the six regions is shown in Table 2. Region I had the biggest area $\left(7.49 \times 10^{7}\right.$ ha on average), which was twice or three times greater than that of other regions. There was a large amount of high quality croplands in Region I because of the low terrain and the excellent hydrothermal conditions. Inversely, the cropland areas of Regions IV and VI only accounted for $10 \%$ and 3\% of that of Region I because of the poor hydrothermal conditions. The spatial structure and distribution of cropland were mainly influenced by the natural environment, thus area of cropland varied with the geographical conditions.

\subsubsection{Geomorphologic Region I (Eastern hilly plains)}

The cropland area in Region I increased by $1.35 \times 10^{6}$ ha with an annual amount of $5.4 \times 10^{4}$ ha. The increase rate of cropland during 1990-2000 was more rapid than that during 2000-2015 (Figure 6). The newly reclaimed cropland area was the largest during 1990-1995, which was twice to sixteen times greater than that of other study periods. Woodland, grassland and unused land were the main source types of the newly reclaimed cropland in Songnen Plain, Liaohe Plain, Sanjiang Plain and other parts of northeast China. However, there was little cropland in eastern coastal areas. The newly reclaimed cropland concentrated on Liaohe Plain by the conversion of grassland during 1990-1995 and Songnen Plain by the conversion of woodland during 1995-2000.

The lost cropland was mainly in the vicinity of northeastern provincial capital cities and eastern coastal areas. The ratio between newly built-up land and lost cropland continued to increase; making up $37 \%$ of the total newly reclaimed cropland area during 1990-1995 to 91\% of that during 2010-2015. Along with the rapid economic development, urban expansion accelerated continuously and the traffic network continued to improve. Large built-up areas replaced cropland with an increasing rate in northeastern provincial capital cities, the Beijing-Tianjin-Hebei region and eastern coastal areas (especially the Yangtze River Delta). Because of the low terrain and easily exploited land in Region I, high productivity and high-quality cropland became the best choice for urban expansion. The change from built-up land to cropland continued to accelerate. However, the newly supplied cropland was mainly made up of woodland, grassland and unused land. As a result, there was a serious decline in cropland quality in this region.

\subsubsection{Geomorphologic Region II (Southeastern low and middle mountains)}

Over the whole study period, the cropland in Region II decreased continuously from $3.35 \times 10^{7}$ ha to $3.30 \times 10^{7}$ ha, with an annual amount of $5.9 \times 10^{4}$ ha (Figure 7).

A small increase in cropland mainly took place in 1990-2005. Specifically, it concentrated on southern Guangxi by the conversion of woodland (47.4\%), water bodies and 
Table 2 Temporal and spatial change characteristics of cropland in different geomorphologic regions

\begin{tabular}{|c|c|c|c|}
\hline $\begin{array}{c}\text { Geomorphological } \\
\text { regions }\end{array}$ & $\begin{array}{c}\text { Changes in cropland } \\
\text { area }\left(10^{4} \mathrm{ha} / \mathrm{a}\right)\end{array}$ & $\begin{array}{l}\text { Characteristics of newly } \\
\text { reclaimed cropland }\end{array}$ & Characteristics of lost cropland \\
\hline $\begin{array}{l}\text { Region I } \\
\text { (Eastern hilly } \\
\text { plains) }\end{array}$ & +5.40 & $\begin{array}{l}\text { It was mainly converted from } \\
\text { grassland and unused land, } \\
\text { concentrating on Songnen Plain, } \\
\text { Liaohe Plain, and Sanjiang Plain }\end{array}$ & $\begin{array}{l}\text { It was mainly reclaimed to built-up } \\
\text { land, and occurred in the vicinity of } \\
\text { northeastern provincial capital cities } \\
\text { and eastern coastal areas (especially } \\
\text { Yangtze River Delta). The proportion } \\
\text { of converting built-up land to cropland } \\
\text { continued to increase. }\end{array}$ \\
\hline $\begin{array}{l}\text { Region II } \\
\text { (Southeastern low } \\
\text { middle mountains) }\end{array}$ & -5.92 & $\begin{array}{l}\text { The increased reclaimed crop- } \\
\text { land occurred mainly during } \\
\text { 1990-2000. And it concentrated } \\
\text { on southern Guangxi by the } \\
\text { conversion of woodland, Dong- } \\
\text { ting Lake and Poyang Lake by } \\
\text { the conversion of water body. }\end{array}$ & $\begin{array}{l}\text { Its area was far more than the re- } \\
\text { claimed cropland. Most of the de- } \\
\text { creased cropland was changed to } \\
\text { woodland (low-middle mountains, hills } \\
\text { and valleys of Zhejiang and Fujian } \\
\text { provinces) and built-up land (the Pearl } \\
\text { River Delta and southeastern coastal } \\
\text { areas) during 1990-2000. }\end{array}$ \\
\hline $\begin{array}{l}\text { Region III } \\
\text { (Northern China } \\
\text { and Inner Mongo- } \\
\text { lia eastern-central } \\
\text { mountains and } \\
\text { plateaus) }\end{array}$ & -0.15 & $\begin{array}{l}\text { It mainly occurred in } \\
\text { 1990-2005, with grassland } \\
\text { reclamation in domination. It } \\
\text { was primarily distributed in } \\
\text { upland plains of northeastern } \\
\text { Inner Mongolia, Hetao Plain } \\
\text { and western Loess Plateau. And } \\
\text { the proportion of grassland to } \\
\text { reclaimed cropland was gradu- } \\
\text { ally reducing. }\end{array}$ & $\begin{array}{l}\text { Most serious loss occurred in } \\
\text { 1990-2005, with the conversion from } \\
\text { cropland to grassland, especially in } \\
\text { 1990-1995. The effect of returning } \\
\text { farmland to forests and pastures was } \\
\text { significant in the central part of the } \\
\text { Hetao Plain and at bend of the Yellow } \\
\text { River. }\end{array}$ \\
\hline $\begin{array}{l}\text { Region IV } \\
\text { (Northwestern } \\
\text { middle and high } \\
\text { mountains, basins } \\
\text { and plateaus) }\end{array}$ & +8.93 & $\begin{array}{l}\text { The reclaimed cropland mostly } \\
\text { came from the conversion of } \\
\text { grassland, scattering on oasis } \\
\text { areas with better conditions of } \\
\text { water and land resources, in- } \\
\text { cluding northern Tarim Basin } \\
\text { (Aksu and Korla), Junggar } \\
\text { Basin and so on. }\end{array}$ & $\begin{array}{l}\text { The cropland loss was not apparent in } \\
\text { Region IV with most serious loss oc- } \\
\text { curring in 1990-1995, and } 67.2 \% \text { of } \\
\text { them converted to grassland. This } \\
\text { happened mainly on the fringes of } \\
\text { cropland or peripheries of cities and } \\
\text { towns because of serious cropland } \\
\text { abandonment. }\end{array}$ \\
\hline $\begin{array}{l}\text { Region V } \\
\text { (Southwestern } \\
\text { middle and low } \\
\text { mountains, pla- } \\
\text { teaus and basins) }\end{array}$ & -2.83 & $\begin{array}{l}\text { The change of cropland was } \\
\text { much smaller than regions I and } \\
\text { IV. The reclaimed cropland } \\
\text { emerged in } 1990-2000 \text {, by the } \\
\text { conversion from woodland and } \\
\text { grassland (above } 88.2 \% \text { ). There } \\
\text { were plenty of forests and shrub } \\
\text { lands to be re-cultivated in hills, } \\
\text { mountains valleys of Hubei, } \\
\text { Guizhou, and Yunnan prov- } \\
\text { inces. }\end{array}$ & $\begin{array}{l}\text { With the accelerated industrialization } \\
\text { and urbanization, a great deal of crop- } \\
\text { land was exploited to built-up land, and } \\
\text { the proportion of cropland converted to } \\
\text { built-up land was gradually increasing. }\end{array}$ \\
\hline $\begin{array}{l}\text { Region VI } \\
\text { (Tibetan Plateau) }\end{array}$ & +0.06 & Almost unchanged. & Almost unchanged. \\
\hline
\end{tabular}

grassland during 1990-1995, Dongting Lake and Poyang Lake by the conversion from water body during 1995-2005. These results showed that a serious reclamation of cropland from lakes took place during this period.

Most of the decreased cropland was changed to woodland and built-up land during 1990-2000. The newly reclaimed woodland was mainly distributed in low-middle mountains, 


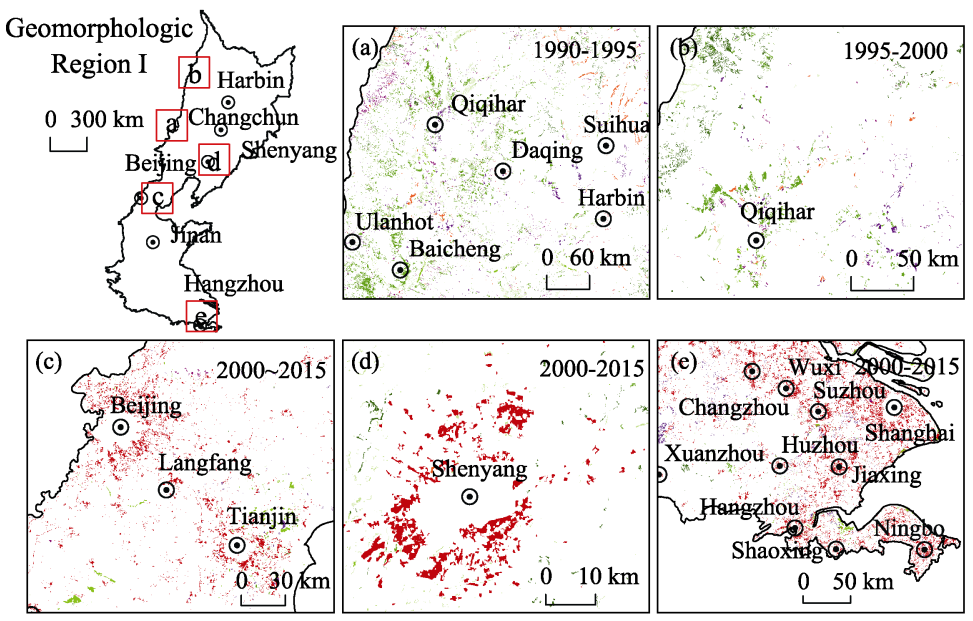

Legend

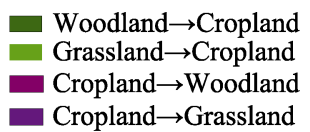

Water body $\rightarrow$ Cropland
Built-up land $\rightarrow$ Cropland
Cropland $\rightarrow$ Water body
Cropland $\rightarrow$ Built-up land $\quad$ Cropland $\rightarrow$ Unused land

Figure 6 Change in reclaimed and lost cropland in Geomorphologic Region I during 1990-2015 Notes: (a)-(e) are local enlarged drawings of Geomorphologic Region I.

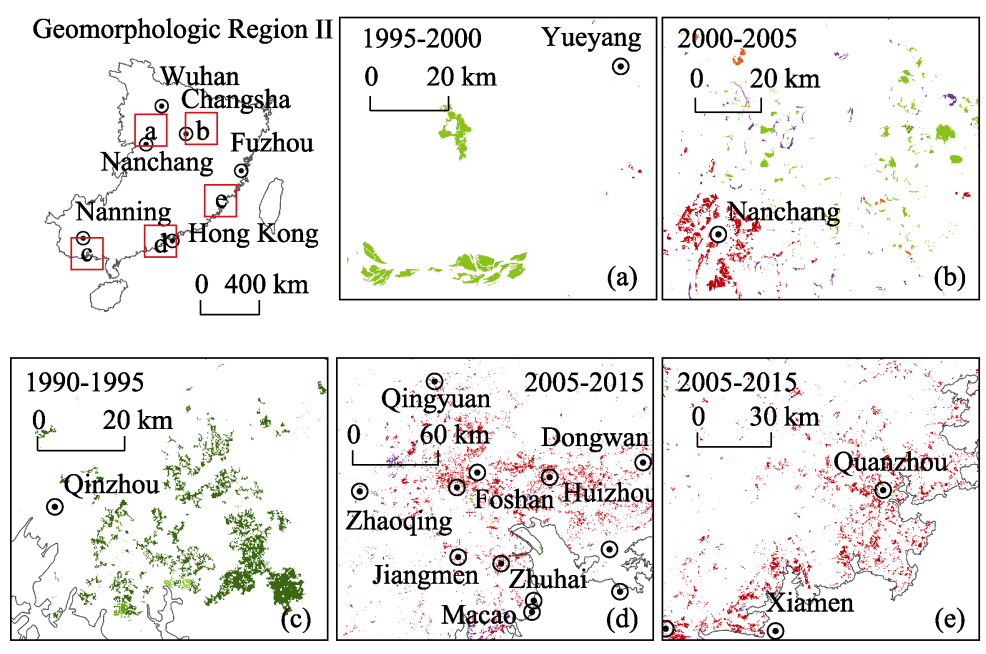

Area of cropland $\left(10^{4} \mathrm{ha}\right)$

Legend

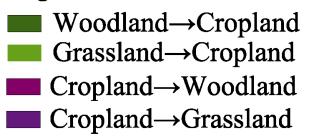

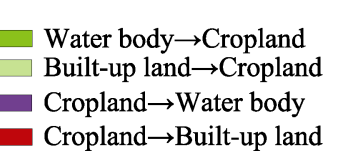

Unused land $\rightarrow$ Cropland

Cropland $\rightarrow$ Unused land

Figure 7 Change in reclaimed and lost cropland in Geomorphologic Region II during 1990-2015 Notes: (a)-(e) are local enlarged drawings of Geomorphologic Region II.

hills and valleys of Zhejiang and Fujian provinces, where afforestation was visible on the cold bare sloping land. Most of the decreased cropland was turned to built-up land during 2000-2015. The major periods of converting cropland to built-up land were 2000-2005 and 2010-2015, with areas of $3.95 \times 10^{5}$ ha and $3.64 \times 10^{5}$ ha, respectively. The newly reclaimed built-up land was concentrated on the Pearl River Delta and southeastern coastal areas dur- 
ing 2000-2010. It was widely distributed in southeastern cities until 2015 with the extension of urbanization scale.

3.3.3 Geomorphologic Region III (Northern China and Inner Mongolia eastern-central mountains and plateaus)

In this region, the cropland decreased slightly by $3.8 \times 10^{4}$ ha over the whole period, with an average loss of $1.5 \times 10^{3}$ ha per year (Figure 8). Grassland was the main source of the newly reclaimed cropland, making up $80 \%, 69 \%$ and $75 \%$ of the total cropland area in the periods of 1990-1995, 1995-2000 and 2000-2005, respectively. The change mainly occurred in upland plains of northeastern Inner Mongolia, Hetao Plain and the western Loess Plateau. The rate of grassland conversion to cropland reduced gradually over time.

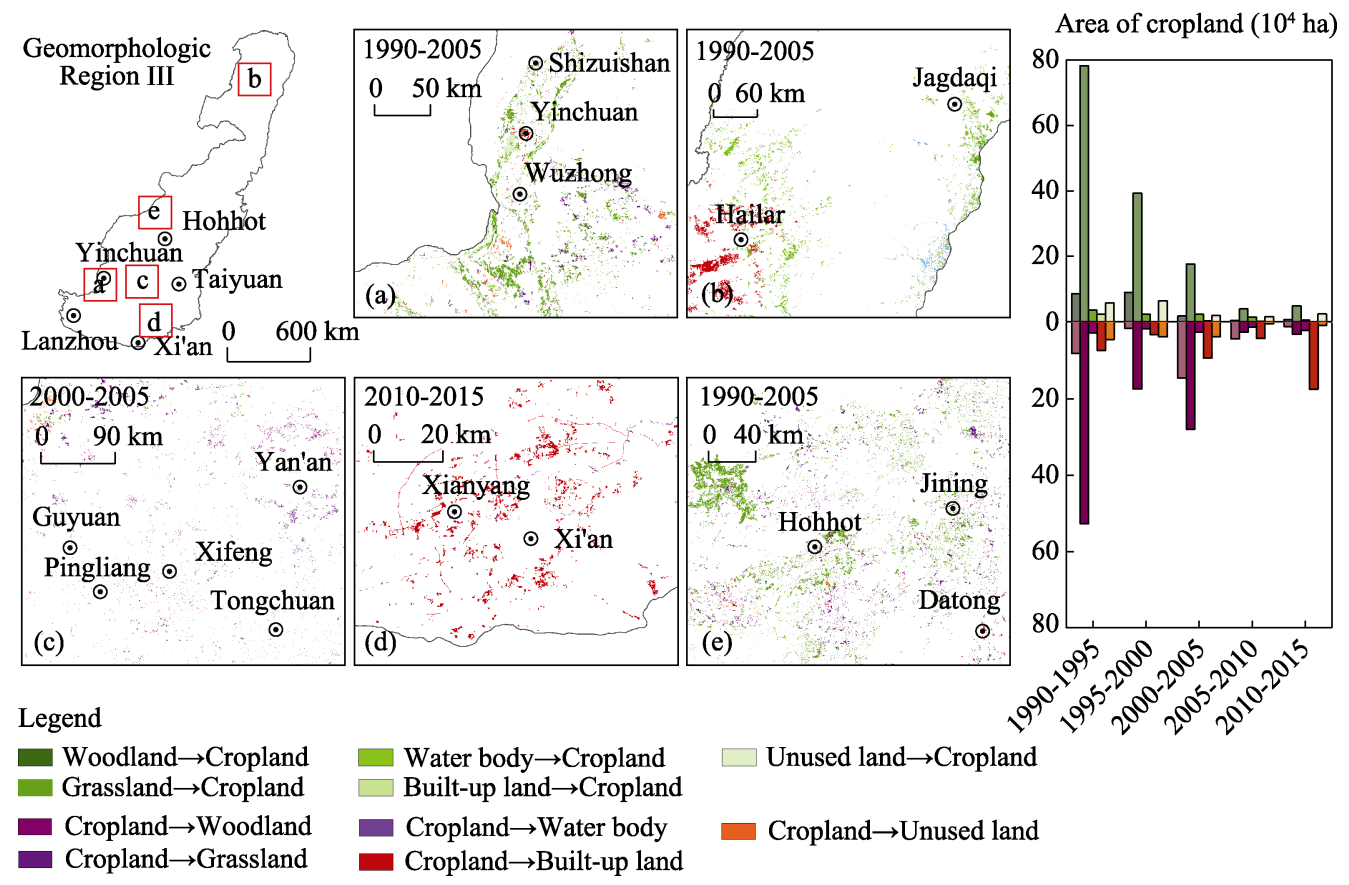

Figure 8 Change in reclaimed and lost cropland in Geomorphologic Region III during 1990-2015 Notes: (a)-(e) are local enlarged drawings of Geomorphologic Region III.

Cropland loss mainly took place in 1990-2005, particularly with the conversion from cropland to grassland in 1990-1995 (5.27 $\times 10^{5}$ ha). The change of cropland to woodland and grassland mainly occurred in the whole Hetao Plain during 1990-1995, in the northern Hetao Plain during 1995-2000, and in central part of the Loess Plateau during 2000-2005.

Compared with the spatial distribution of cropland change in 1990-2005, the newly reclaimed and lost cropland were both concentrated on Hetao Plain and the Loess Plateau. This change reflected that the effect of returning farmland to forests and pastures was evident on the one hand while on the other hand new cropland should be added at the same time.

Lots of cropland was converted to built-up land during 2010-2015, particularly in the central parts of both Shaanxi and Gansu provinces.

3.3.4 Geomorphologic Region IV (Northwestern middle and high mountains, basins and plateaus) Region IV witnessed an increase in cropland area of $2.23 \times 10^{6}$ ha with an annual average of 
$8.9 \times 10^{4}$ ha during 1990-2015, and its newly reclaimed cropland area was the largest of the six geomorphologic regions. The main changes in land-use types in this region were between cropland and grassland (Figure 9).

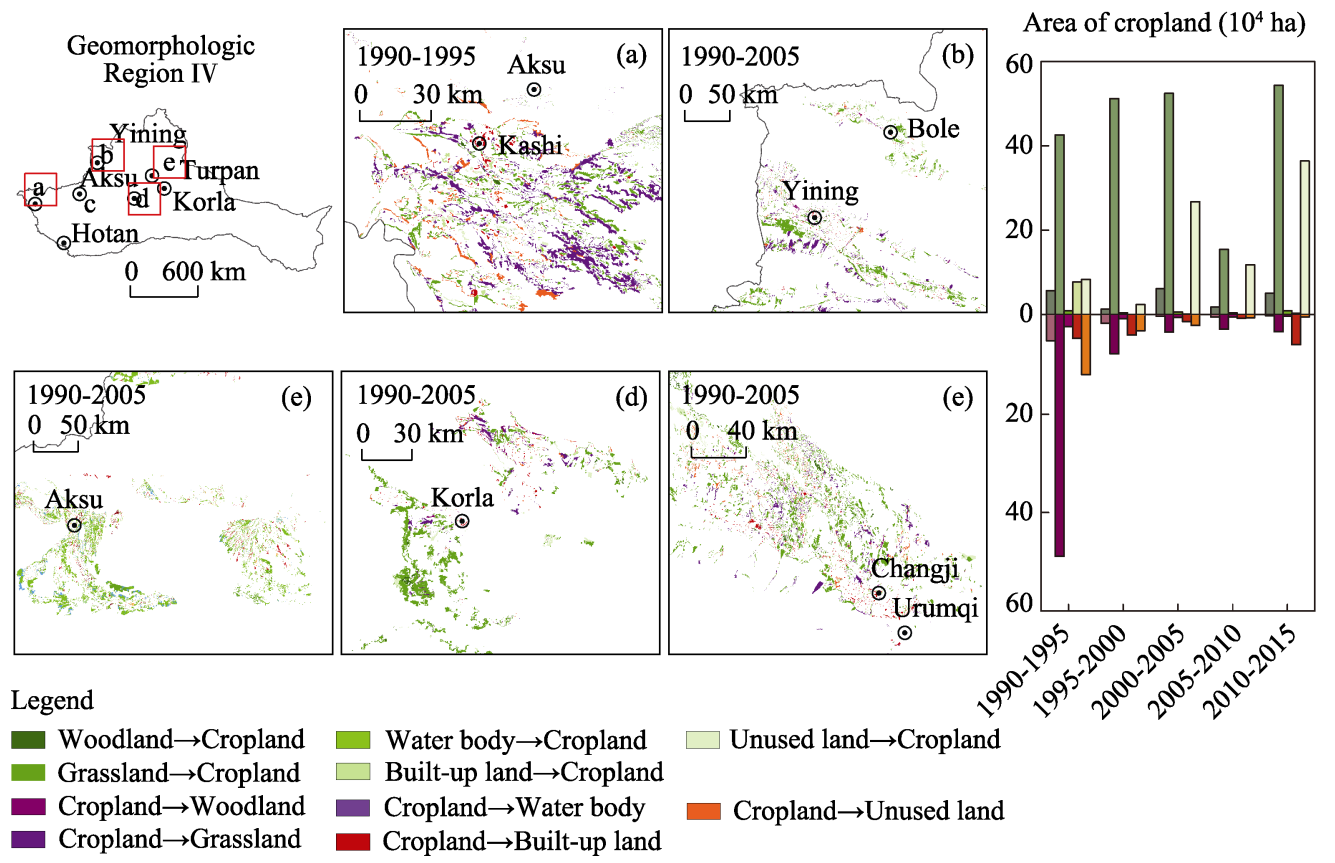

Figure 9 Change in reclaimed and lost cropland in Region IV during 1990-2015 Notes: (a)-(e) are local enlarged drawings of Geomorphologic Region IV.

The newly reclaimed cropland mostly came from the conversion of grassland, scattered in oasis areas with better conditions of water and land resources, including northern Tarim Basin (Aksu and Korla) and Junggar Basin. In order to encourage farmers to reclaim cropland, many preferential policies and facilitation measures were proposed and carried out by the central government and Xinjiang local government, including grain production subsides and agricultural tax exemption. In particular, the speed and quantity of cropland exploration peaked during 2000-2005.

Cropland losses were not apparent in Region IV during 1995-2015. The lost area of cropland reached $7.3 \times 10^{5}$ ha only in the period of $1990-1995$, and $67.2 \%$ of the lost cropland was converted to grassland. The lost cropland was spread on the fringes of cropland or peripheries of cities and towns. Cropland loss was particularly serious in the Kashi area because of widespread cropland abandonment during this period.

3.3.5 Geomorphologic Region V (Southwestern middle and low mountains, plateaus and basins)

Over the whole study period, the cropland in Region V continuously decreased by $7.1 \times 10^{5}$ ha in total, with an annual area of $2.8 \times 10^{4}$ ha. The change in cropland was much smaller than in Regions I and IV. The newly reclaimed cropland emerged in 1990-2000, mostly from conversion from woodland and grassland (above $88.2 \%$ ). There were plenty of forests and shrub lands available for cultivation in the hills and mountains valleys of Hubei, Guizhou and Yunnan provinces. However, the area of newly reclaimed cropland was small 
during 2000-2005 in this region (Figure 10).

With the accelerated industrialization and urbanization, a great deal of cropland was exploited as built-up land and the proportion of cropland converted to built-up land was gradually increasing. The conversion of cropland to built-up land was mainly concentrated in provincial capitals or large cities.

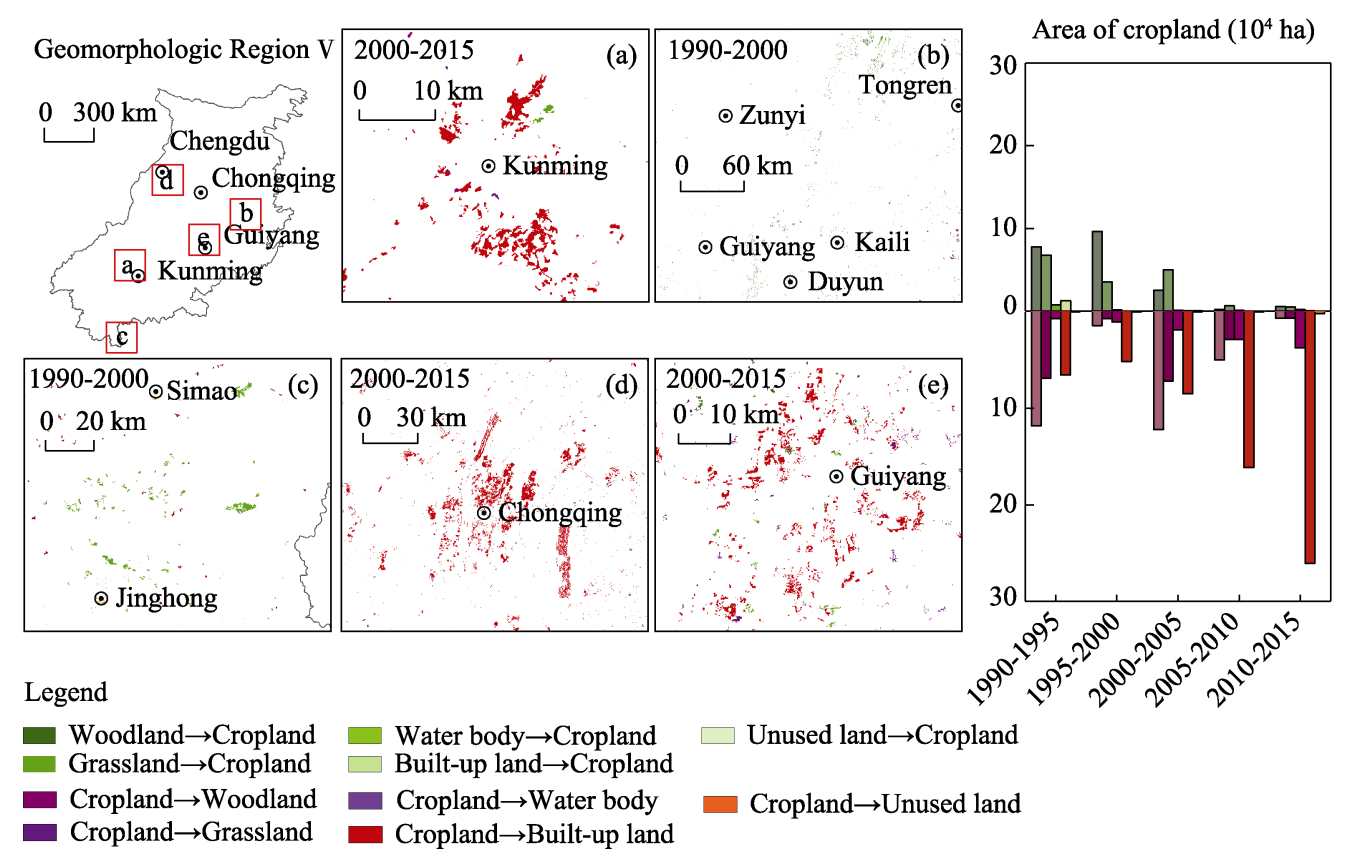

Figure 10 Change of reclaimed and lost cropland in Geomorphologic Region V during 1990-2015 Notes: (a)-(e) are local enlarged drawings of Geomorphologic Region V.

\subsubsection{Geomorphologic Region VI (Tibetan Plateau)}

Because of the complicated topographical conditions, small resident population and underdeveloped economy, the cropland area changed very little in Region VI and only increased by 60 ha annually (Figure 11). Newly reclaimed cropland was converted from grassland. The lost cropland was very small and was mainly converted to grassland and built-up land.

\section{Discussion and conclusions}

Cropland is one of the most sensitive and fragile land-use types. With the accelerated industrialization and urbanization, both the quantity and quality of cropland is faced with severe challenges and many problems. With the aid of the GIS technique, we extracted cropland data, analyzed the spatial structure and distribution of China's cropland, and discussed the relationship between cropland and other land-use types in the period of 1990-2015.

There was little change in the total cropland area in China during 1990-2015. The cropland was distributed mainly on the second and the third topographical steps of central and eastern China. The barycenter of China's cropland shifted from northern China to the northwest. The rapid urbanization and the occupation of high-quality cropland were the critical factors influencing the spatio-temporal distribution of cropland in China.

There was a large number of high-quality cropland in Region I because of the low terrain 

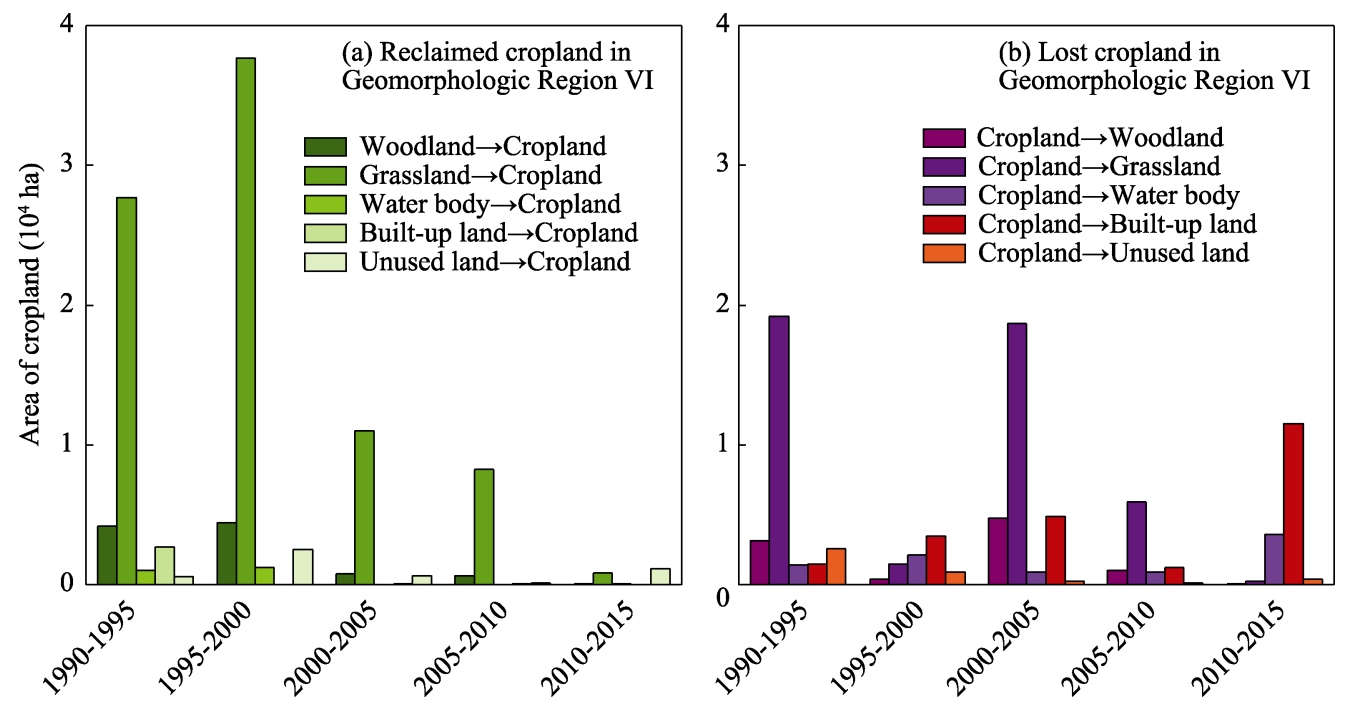

Figure 11 Change in the reclaimed and lost cropland in Geomorphologic Region VI during 1990-2015

and abundant water resources. Region I has the largest cropland area, covering an average area of $7.49 \times 10^{7}$ ha. Inversely, the cropland areas of Regions IV and VI accounted for less than $10 \%$ of that of Region I because of the complicated geographical conditions and the extensively distributed mountains, plateaus and basins.

Owing to the large area of the geomorphologic regions, the DDC values were relatively small. In region IV, the cropland areas fluctuated greatly with DDC values far exceeding those of other regions, having an annual average increasing amount of $8.9 \times 10^{4}$ ha. The DDC values in Region IV were 4.06\%, 2.62\% and 2.61\% during 1990-1995, 2000-2005 and 2010-2015, respectively. The newly reclaimed croplands were mainly from the exploitation of grassland areas distributed across the northern Tarim Basin (Aksu and Korla) and Junggar Basin. However, the DDC values in other regions were less than $1 \%$.

From the perspective of land-use types, the newly reclaimed cropland primarily came from grassland, woodland and unused land, especially during 1990-2000. The lost cropland was mainly converted to built-up land, woodland and grassland during 1990-2015. The principal reason for cropland losses was that a large amount of high-quality cropland was indiscriminately occupied by built-up land. From the perspective of geomorphologic regions, the newly reclaimed and lost cropland was concentrated on vast plains $(58.6 \%$ and $60.9 \%$, respectively), followed by platforms and hills. The larger the relief amplitude, the smaller the cropland area.

The newly reclaimed cropland mainly occurred in Regions I and IV, and the lost cropland mainly occurred in Regions II and V. There was no change in cropland area in Regions III and VI.

However, we only analyzed spatio-temporal distribution of cropland in China during 1990-2015 based on geomorphologic regionalization. The main drivers of cropland change need to be explored deeply in different geomorphologic regions. Cropland serves as an essential base and guarantee for human survival and development. Cropland protection is related to food security, sustainable development and social stability. Further research is therefore needed focusing on reasonable utilization and risk assessment of China's cropland 
based on geomorphologic regionalization.

\section{Acknowledgements}

We thank Alex Boon, PhD, from Liwen Bianji, Edanz Editing China (www.liwenbianji. $\mathrm{cn} / \mathrm{ac}$ ), for editing the English text of a draft of this manuscript. We also thank Professor Liu Yongbo in the University of Guelph for checking and revising the language, and the editor and anonymous reviewers for their labor and precious time for improving our manuscript.

\section{References}

Chen L G, 2001. Sustainable development of agriculture and sustainable use of farmland resources in China. Journal of Anhui Agricultural University, 28(1): 102-105. (in Chinese)

Cheng W M, Chai H X, Fang Y et al., 2012. Analysis of cultivated land based on water resources regionalization and geomorphologic characteristics in Xinjiang, China. Journal of Natural Resources, 27 (11): 1809-1822. (in Chinese)

Cheng W M, Zhou C H, Li B Y et al., 2011. Structure and contents of layered classification system of digital geomorphology for China. Journal of Geographical Sciences, 21(5): 771-790.

Fu J X, Chang Q R, Li F L et al., 2011. Evaluation of farmland productivity in complex topography regions of Loess Plateau based on GIS: A case study in Chengcheng County of Shaanxi Province. Geography and Geo-Information Science, 27(4): 57-61. (in Chinese)

Hao H M, Ren Z Y, 2009. Land use/land cover change (LUCC) and eco-environment response to LUCC in farming-pastoral zone, China. Journal of Integrative Agriculture, 8(1): 91-97.

He W C, Zhao S M, Cheng W M, 2016. Analysis of land cover change on basic geomorphic types in Shanxi Province. Geography and Geo-Information Science, 18(2): 210-219. (in Chinese)

Kotoky P, Dutta M K, Borah G C, 2012. Changes in landuse and landcover along the Dhansiri River channel, Assam: A remote sensing and GIS approach. Journal of the Geological Society of India, 79(1): 61-68.

Kraemer R, Prishchepov A V, Müller D et al., 2015. Long-term agricultural land-cover change and potential for cropland expansion in the former Virgin Lands area of Kazakhstan. Environmental Research Letters, 10(5): 345-466.

Li B Y, Pan B T, Cheng W M et al., 2013. Research on geomorphologic regionalization of China. Acta Geographica Sinica, 68(3): 291-306. (in Chinese)

Li C, Wu K, 2017. Driving forces of the villages hollowing based on geographically weighted regression model: A case study of Longde County, the Ningxia Hui Autonomous Region, China. Natural Hazards, 89(3): 1059-1079.

Li T, Long H, Zhang Y et al., 2017. Analysis of the spatial mismatch of grain production and farmland resources in China based on the potential crop rotation system. Land Use Policy, 60: 26-36.

Liu H Y, Kuang W H, Zhang Z X et al., 2014. Spatiotemporal characteristics, patterns, and causes of land-use changes in China since the late 1980s. Journal of Geographical Sciences, 24(2): 195-210.

Liu J Y, Liu M L, Tian H Q et al., 2005. Spatial and temporal patterns of China's cropland during 1990-2000: An analysis based on Landsat TM data. Remote Sensing of Environment, 98(4): 442-456.

Liu J Y, Zhang Z X, Xu X L et al., 2010. Spatial patterns and driving forces of land use change in China during the early 21 st century. Journal of Geographical Sciences, 20(4): 483-494.

Liu M L, Zhuang D F, Hu W Y, 2001. On current cultivated land change based on geomorphology and spatial differentiation characteristics. Resources Science, 23(5): 11-16. (in Chinese)

Liu X B, Zhang X Y, Wang Y X et al., 2010. Soil degradation: A problem threatening the sustainable development of agriculture in Northeast China. Plant Soil \& Environment, 56(2): 87-97.

Liu Y, Yang R, Li Y H, 2013. Potential of land consolidation of hollowed villages under different urbanization scenarios in China. Journal of Geographical Sciences, 23(3): 503-512. 
Ning J, Liu J Y, Kuang W H et al., 2018. Spatiotemporal patterns and characteristics of land-use change in China during 2010-2015. Journal of Geographical Sciences, 28(5): 547-562.

Peng J, Liu Y X, Li T Y et al., 2017. Regional ecosystem health response to rural land use change: A case study in Lijiang City, China. Ecological Indicators, 72: 399-410.

Ren W, Tian H, Tao B et al., 2012. China's crop productivity and soil carbon storage as influenced by multifactor global change. Global Change Biology, 18(9): 2945-2957.

Restrepo A M C, Yang Y R, Hamm N A S et al., 2017. Land cover change during a period of extensive landscape restoration in Ningxia Hui Autonomous Region, China. Science of the Total Environment, 598: 669-679.

Song N P, Chen Z X, 1993. A study on the relationship of landform and landuse. Journal of Ningxia University (Natural Science Edition), 14(3): 27-31. (in Chinese)

Stevens F, Bogaert P, Van O K et al., 2014. Regional-scale characterization of the geomorphic control of the spatial distribution of soil organic carbon in cropland. European Journal of Soil Science, 65(4): 539-552.

Tian H Q, Chen G S, Lu C Q et al., 2015. Global methane and nitrous oxide emissions from terrestrial ecosystems due to multiple environmental changes. Ecosystem Health \& Sustainability, 1(1): 1-20.

Tian H Q, Ren W, Tao B et al., 2016. Climate extremes and ozone pollution: A growing threat to China's food security. Ecosystem Health \& Sustainability, 2(1): 1-10.

Tian M, Gao M, Bao J X et al., 2010. The effect of topography and geomorphology on the amount of newly-increased cultivated land. Journal of Southwest University (Natural Science Edition), 32(11): 98-103. (in Chinese)

Turner B L, Lambin Eric F, Reenberg Anette, 2007. The emergence of land change science for global environmental change and sustainability. Proceedings of the National Academy of Sciences of the United States of America, 104(52): 20666.

Wang J, Zhang Z, Liu Y, 2018. Spatial shifts in grain production increases in China and implications for food security. Land Use Policy, 74: 204-213.

Yan F Q, Zhang S W, Kuang W H et al., 2016. Comparison of cultivated landscape changes under different management modes: A case study in Sanjiang Plain. Sustainability, 8(10): 1071. doi: 10.3390/su8101071.

Yang R H, Yang Q Y, Zeng L et al., 2017. Evaluation on ecological security and analysis of influence factors of rural land based on BP-ANN model. Research of Soil and Water Conservation, 24(3): 206-213. (in Chinese)

Yao Z Y, Zhang L J, Tang S H et al., 2017. The basic characteristics and spatial patterns of global cultivated land change since the 1980s. Journal of Geographical Sciences, 27(7): 771-785.

Ye Y, Fang X Q, Ren Y Y et al., 2009. Cropland cover change in Northeast China during the past 300 years. Science in China Series D Earth Sciences, 52(8): 1172-1182.

Yin G, Liu L, Jiang X, 2017. The sustainable arable land use pattern under the tradeoff of agricultural production, economic development, and ecological protection: An analysis of Dongting Lake basin, China. Environmental Science \& Pollution Research, 24(32): 1-17.

Zhao G S, Liu J Y, Kuang W H et al., 2015. Disturbance impacts of land use change on biodiversity conservation priority areas across China: 1990-2010. Journal of Geographical Sciences, 25(5): 515-529.

Zhao M, Cheng W M, Zhou C H et al., 2017. Spatial differentiation and morphologic characteristics of China's urban core zones based on geomorphologic partition. Journal of Applied Remote Sensing, 11(1): 016041. doi: 10.1117/1.JRS.11.016041.

Zhou C H, Cheng W M, Qian J K et al., 2009. Research on the classification system of digital land geomorphology of 1:1000000 in China. Journal of Geo-Information Science, 11(6): 707-724. (in Chinese) 